\title{
PHOTOCATALYTIC COATINGS - PROMISING WAY TO IMPROVE A QUALITY OF URBAN BUILDING SURFACES
}

\author{
POWŁOKI FOTOKATALITYCZNE - OBIECUJĄCY SPOSÓB POPRAWY \\ JAKOŚCI POWIERZCHNI BUDYNKÓW MIEJSKICH
}

\begin{abstract}
With the increasing air pollutants particularly in the cities the deteriorating conditions of the buildings accelerate. One of the non-invasive and cheap promising ways how to prevent the buildings against the aged processes caused by biological pollutants or smog exhalation is the innovation of suitable photocatalytic coatings. This work focuses on the characterization of prepared photocatalytic nanocomposite $\mathrm{TiO}_{2}-\mathrm{SiO}_{2}$ system to be applied on the building objects in order to improve a quality of their surfaces. The structure and the texture characterization of prepared nanocomposite were determined by electron microscopy (SEM, TEM + EDS). The photocatalytic activity of the composite was determined considering the self-cleaning ability and the antibacterial activity. For self-cleaning characterization the methylene blue degradation was measured. These self-cleaning properties were tested on the various types of supports, which are commonly used in the building facades. To estimate antibacterial and biocidal activity the Gram-negative bacterium Escherichia coli and the gram-positive bacteria Staphylococcus aureus were used. Both methods were done according to standard ISO tests. Next to the laboratory testing the application of the composite under the real condition was implemented. There were treated parts of the concrete outside wall with the composite and after more than one year the colour changed analysis of the wall surface was characterized.
\end{abstract}

Keywords: $\mathrm{TiO}_{2}-\mathrm{SiO}_{2}$ nanocomposite, photoactive, transparent coatings, self-cleaning surfaces, antibacterial photocatalytic activity, architectural heritage

\section{Introduction}

Causes of building decay are complex. According to climate causes such as sun, moisture and wind there are also biological and air pollutant ones. With dramatically deteriorating atmospheric air those two mentioned effects are becoming nowadays one of the largest sources of the external building decay. Bacteria, lichens, mosses and fungi can damage the buildings.

Bacteria and lichens produced acids which react chemically with the building materials. Algae, moss and lichens produce humus in which larger and more damaging plants can

\footnotetext{
${ }^{1}$ Technical University of Liberec, Studentská 1402/2 46117 Liberec, Czech Republic

${ }^{2}$ Institute of Inorganic Chemistry AS Czech Republic, v.v.i., Husinec-Řež 1001, 25068 Řež, Czech Republic

*Corresponding author: tereza.sazavska@tul.cz
} 
grow. It can cause retention of moisture in the building material. These deteriorating processes are accelerated by atmospheric pollutants, which in combination with air moisture produce a corrosive mixture. The application of the photocatalytic protection layer which is able to oxidize the microbiological impurity shows to be promising way how to extend life service of the buildings.

In 1972 Fujishima and Honda as a first reported the water splitting on the semiconductor titanium dioxide [1]. Since the photocatalytic properties of semiconductors have been broadly investigated for their capability to convert solar energy into chemical energy to oxidize or reduce appropriate molecules. It can be used for hydrogen and hydrocarbons evaluation, to remove pollutants and bacteria on wall surfaces or in water [2-5]. The photocatalytic properties of the semiconductors are derived from the photogeneration of charge carriers - holes $\left(\mathrm{h}^{+}\right)$and excited electrons $\left(\mathrm{e}^{-}\right)$- which occurs upon the absorption of light corresponding to the band gap. The electron-holes pairs then recombine or participate in redox reactions $[1,6]$. The reductive and oxidative capacity of the photogenerated electrons and holes are determined by the conduction band and valence band potential of the semiconductor particle [7]. The possible processes occurring within the semiconductor particles after the light irradiation are described in Figure $1[8,9]$.

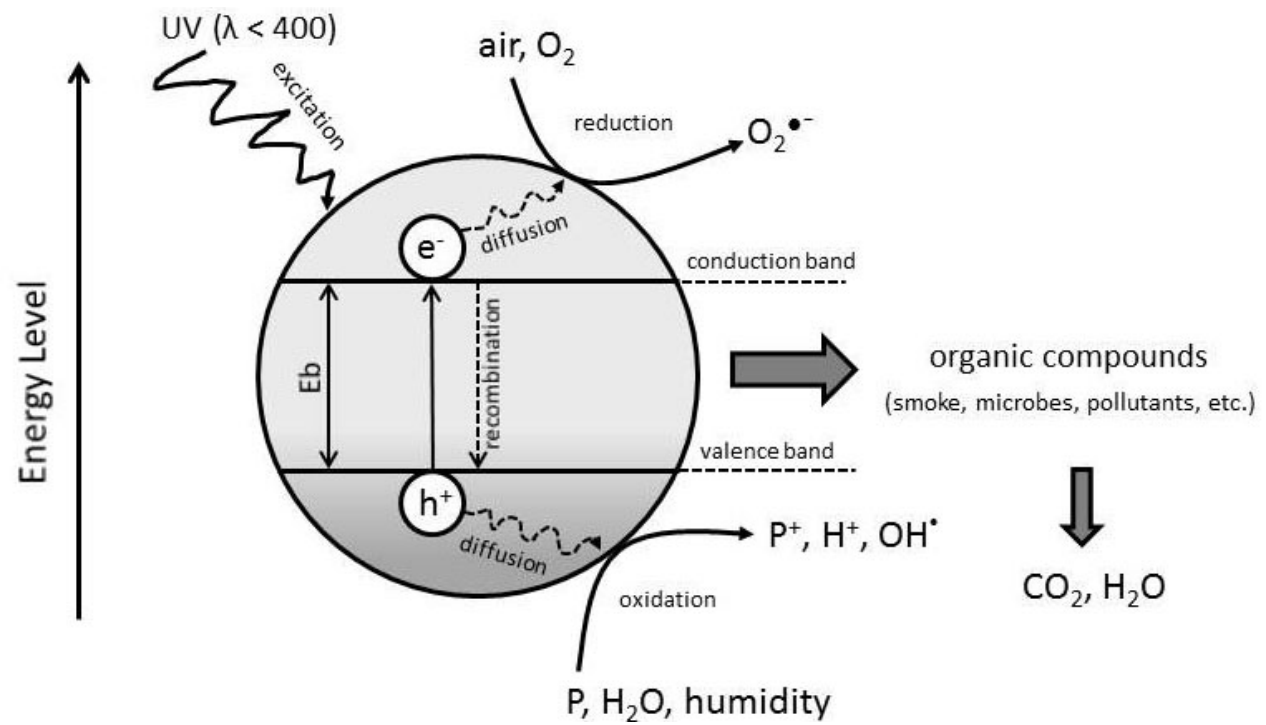

Fig. 1. The schematic illustration of the photocatalytic processes on the semiconductor during the illumination

In case that the electron-hole pair does not recombine, the holes in the valence band may diffuse to the particle surface and react with adsorbed water molecules to give hydroxyl radicals $\left({ }^{\bullet} \mathrm{OH}\right)$. The photogenerated holes and these hydroxyl radicals oxidize adjacent organic molecules on the surface. While the excited electrons in the conduction band generally provide reduction processes, typically the superoxide radical anions $\left(\mathrm{O}_{2}{ }^{\bullet-}\right)$ production during the reaction of the electrons with molecular oxygen in air. The possible reactions are described in Figure $2[1,10]$. 


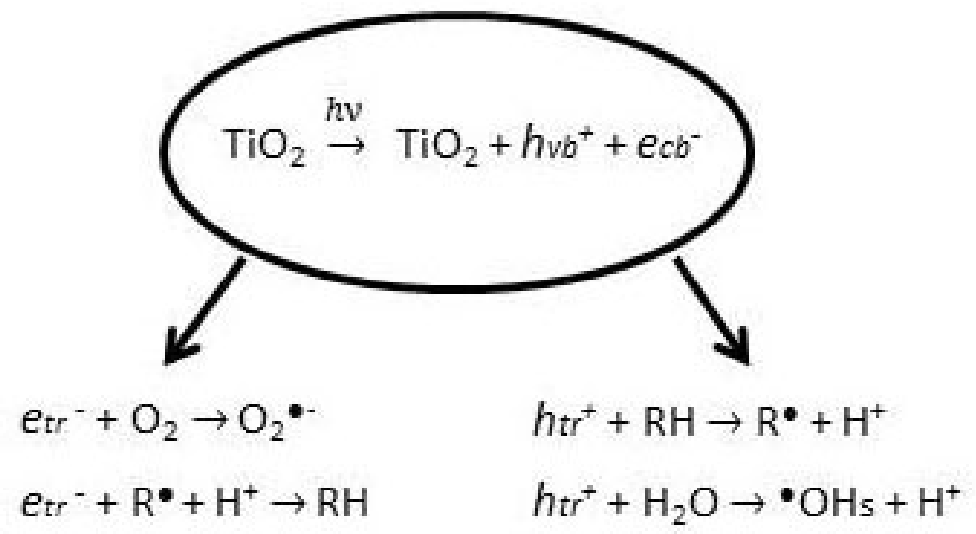

Fig. 2. The mechanism of the radicals and highly oxidizing - reducing molecules production

There are several ways how to increase the photocatalytic activity, one is to limit the electron-hole recombination process. This can be achieved by the life prolongation of the trapped electrons or holes, in such a case there is a higher probability that the charge carriers will react with the adjacent molecules rather than to recombine. Such research is for example focused on the metal doped titanium dioxides. The excited electron may diffuse to the metal particle to be trapped there and react with suitable molecule [11, 12]. Another approach of many researchers is to modify $\mathrm{TiO}_{2}$ electron structure to get narrower band gap. There is an effort to prepare photocatalyst with sufficient activity under the visible light [13, 14]. Nevertheless with narrowing band gap we decrease the capacitance of oxidizing or reduction ability of the photocatalyst.

Titanium dioxide $\left(\mathrm{TiO}_{2}\right)$ is well known photocatalyst. It features an electron structure of $3.0 \mathrm{~V}$ band gap for anatase structure. The photogenerated holes in $\mathrm{TiO}_{2}$ show strong oxidizing ability, is inexpensive, nontoxic and chemically stable. Therefore its photoactive properties have been extensively investigated concerning its promising applications as the light-induced degradation of environmental contaminants [15-18]. Currently the development of self-cleaning coatings based on the photocatalytic properties of titanium dioxide is becoming very promising way how to remove or destroy low level air or biological pollutants $[19,20]$.

\section{Materials and methods}

\section{$\mathrm{TiO}_{2}-\mathrm{SiO}_{2}$ nanocomposite}

The photocatalytic composite paint consists of a photocatalyst and a binder; the photocatalyst nanoparticles are formed by agglomerated $\mathrm{TiO}_{2}$ in water whereas the $\mathrm{SiO}_{2}$ nanoparticles are used in the form of a stabilized aqueous suspension. The nanocomposite was prepared in form of aqueous dispersion containing 1-3\% of dry mater formed by 40 wt. $\%$ of $\mathrm{TiO}_{2}$ and 60 wt. $\%$ of $\mathrm{SiO}_{2}$. The texture of the composite was determined on samples obtained by spraying the aqueous dispersion in liquid nitrogen and immediate lyophilisation the frozen droplets at temperature $-60^{\circ} \mathrm{C}$ and pressure $1.30 \mathrm{kPa}$. Obtained dry 
composite was characterized by electron microscopy (both SEM and TEM + EDS). The surface area and porosity of the lyophilized $\mathrm{SiO}_{2}-\mathrm{TiO}_{2}$ nanocomposite was determined from the BET adsorption isotherm using $\mathrm{N}_{2}$ as adsorbent.

\section{Photocatalytic activity of the composite}

\section{Self-cleaning characterization}

The photocatalytic self-cleaning activity of coatings prepared from such composites was determined using the ISO 10678:2010 standard method based on methylene blue decomposition [21]. Methylene blue is degraded in contact with the photoactive surface under illumination of the surface using an aqueous solution of MB. The light source should be within the wavelength $320<\lambda<400 \mathrm{~nm}$ with the intensity $10 \pm 0.5 \mathrm{~W} / \mathrm{m}^{2}$, to induce the direct photolysis dyes. The amount of dye remaining in solution is determined at regular intervals during the period of illumination by UV/Vis spectroscopy (Perkin Elmer Lambda 35). The reference measurement is carried out with an identical sample without illumination. We prepared and tested different types of support layer for composite coatings - lime plaster, silicon coating, acrylic and silica paint.

The composite was also applied on the concrete outside wall of the building. We determined the effect of the photocatalytic coating on the wall by visual change surface analysis. For the analysis the Flip-Pal plus mobile scanner and the DoSa software application were used to describe the color intensity changes of the surface. This analysis was done after more than one year after the composite application.

\section{Antibacterial characterization}

The composite antibacterial activity was measured on the nonporous glass surfaces. The composite layer was prepared by dip coating method. Such prepared samples were dried at room temperature for 48 hours. Dimension of the test area was $2.5 \mathrm{~cm} \cdot 2.5 \mathrm{~cm}$.

We determined the antibacterial activity according to test method for antimicrobial activity of semiconducting photocatalytic materials ISO 27447/2009. It was used the culture medium - Nutrient Broth - as a medium for production of inoculum. Agar plates were prepared using nutrient agar. It was solid medium for cultivation and keeping of microorganisms. The $\mathrm{pH}$ values of all prepared mediums were adjusted to 7.4.

The tested organisms were the Gram-negative bacterium Escherichia coli and the gram-positive bacteria Staphylococcus aureus. For the strain E. coli was used CCM (Czech type colony collection) 3954. For bacterial strains Staphylococcus aureus was used CCM 3953. The initial concentration of organisms was $3 \cdot 108 \mathrm{cells} / \mathrm{cm}^{3}$. The amount of the freshly prepared bacterial suspension onto glass sample was $150 \mathrm{~mm}^{3}$. The characterization of the antibacterial activity was evaluated on the basis of CFU (colony forming units) assay using the ANOVA statistical method. The numbers of colonies were calculated on the samples which were illuminated by UV light of $0.01 \mathrm{~mW} / \mathrm{cm}^{2}$ intensity and on the samples stayed in the darkness. Exposure time of UV light was $240 \mathrm{~min}$. The experimental setup is shown in Figure 3. 


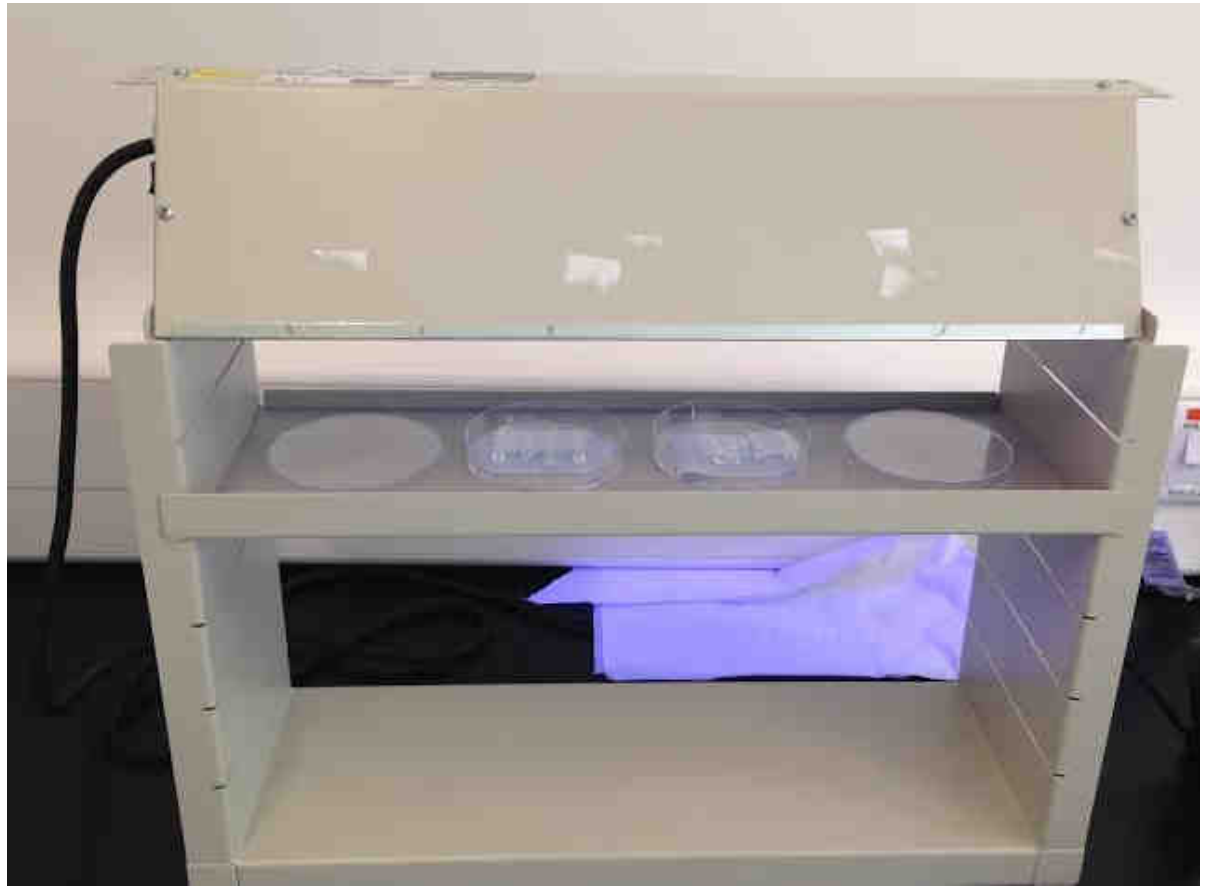

Fig. 3. The experimental setup for the antibacterial effect characterization

\section{Results and discussion}

\section{$\mathrm{TiO}_{2}-\mathrm{SiO}_{2}$ nanocomposite}

The prepared dispersion is stable, sedimentation of solids occurs only after several days and the material can be easily resuspended. SEM micrograph and EDS mapping of a surface coated with the $\mathrm{SiO}_{2}-\mathrm{TiO}_{2}$ nanocomposite is presented in Figure 4. We can observe isolated islands of titanium dioxide photocatalyst (lighter objects on the SEM micrograph) surrounded with the $\mathrm{SiO}_{2}$ matrix. It is evident from this micrograph that the $\mathrm{SiO}_{2}$ matrix is keeping units of aggregated $\mathrm{TiO}_{2}$ photocatalyst separated and can isolate the photocatalyst from direct contact with the substrate on which the material is applied.

The product obtained by lyophilisaton of the $\mathrm{SiO}_{2}-\mathrm{TiO}_{2}$ nanocomposite is presented in Figures 4 and 5. TEM micrograph shows darker aggregates of $\mathrm{TiO}_{2}$ photocatalyst surrounded by lighter $\mathrm{SiO}_{2}$ matrix. The composition of individual objects was determined by EDS and electron diffraction, which demonstrated crystalline objects with anatase structure surrounded by amorphous material. The $\mathrm{SiO}_{2}$ matrix consists of small nanometric spherical objects with clearly visible porosity. Presence of considerable porosity was confirmed also by BET measurements, the surface area of the lyophilized sample of $\mathrm{SiO}_{2}-\mathrm{TiO}_{2}$ nanocomposite was found $98.523 \mathrm{~m}^{2} \cdot \mathrm{g}^{-1}$. 

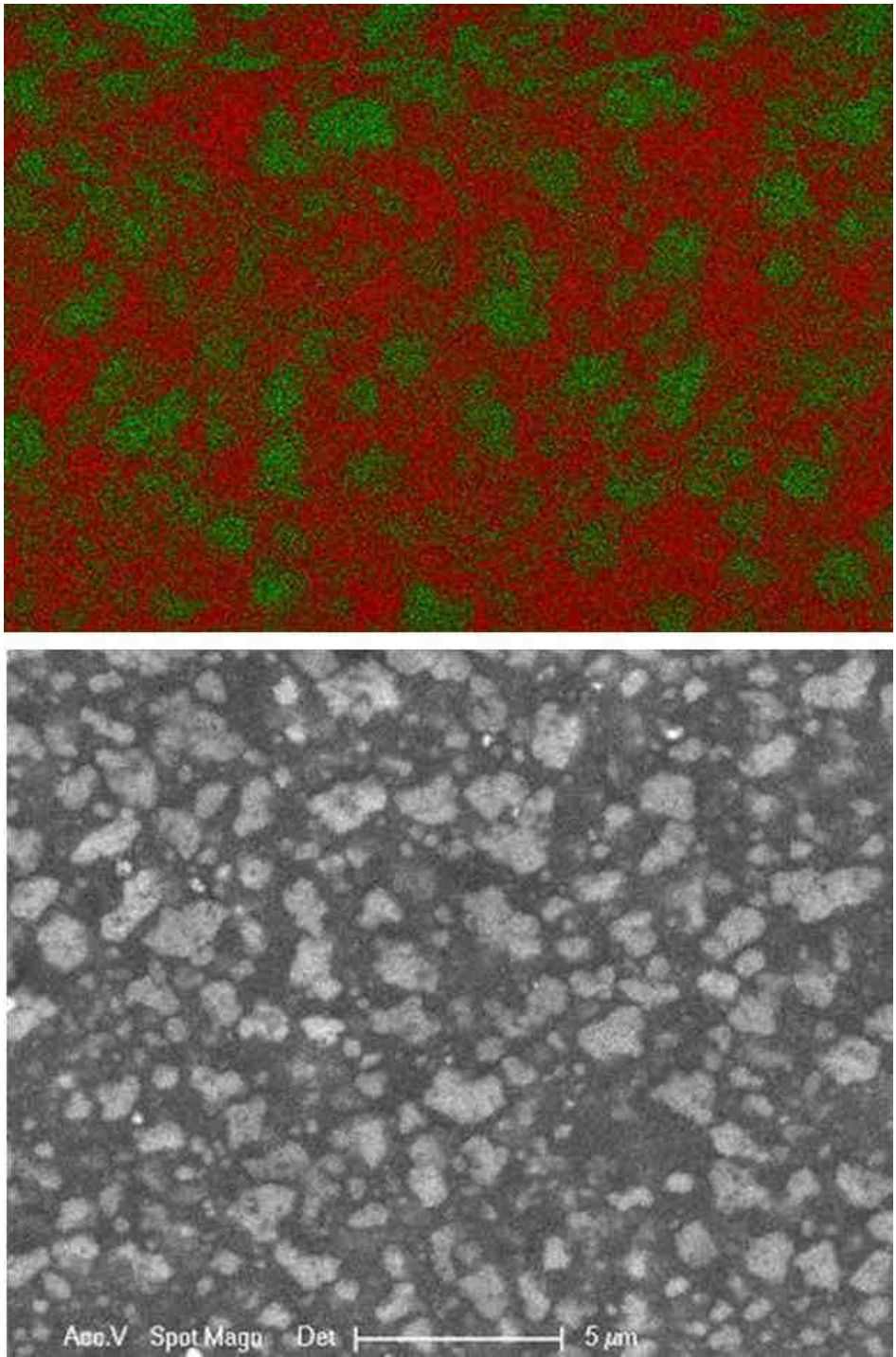

Fig. 4. SEM micrograph of surface coated with the $\mathrm{SiO}_{2}-\mathrm{TiO}_{2}$ nanocomposite (bottom) and EDS mapping (top): green - $\mathrm{TiO}_{2}$, red - $\mathrm{SiO}_{2}$

The appearance of coatings prepared from the $\mathrm{SiO}_{2}-\mathrm{TiO}_{2}$ nanocomposite was either completely transparent or slightly opalescent. We observed that the transparency of coatings is one of the characteristics of the photocatalyst used for preparation of the $\mathrm{SiO}_{2}-\mathrm{TiO}_{2}$ nanocomposite. Generally, the better dispersible photocatalysts provide more transparent coatings than photocatalysts whose crystallites are tightly aggregated. 


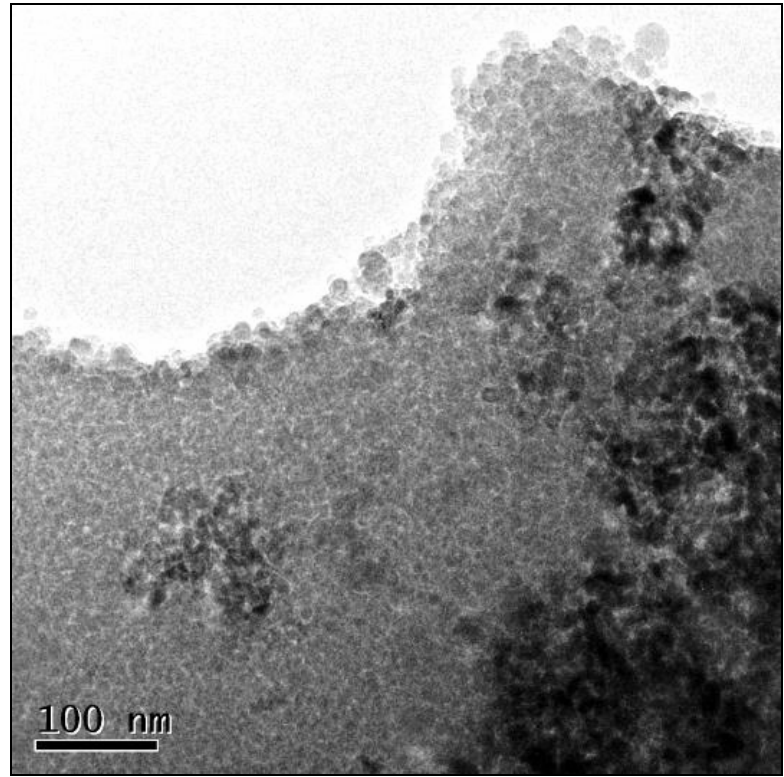

Fig. 5. TEM micrograph of the lyophilized $\mathrm{SiO}_{2}-\mathrm{TiO}_{2}$ nanocomposite

\section{Photocatalytic self-cleaning characterization}

The self-cleaning properties of coatings prepared using our composite material were determined using the methylene blue decolorization. The drop of absorbance related to methylene blue decomposition is given in Figure 6.

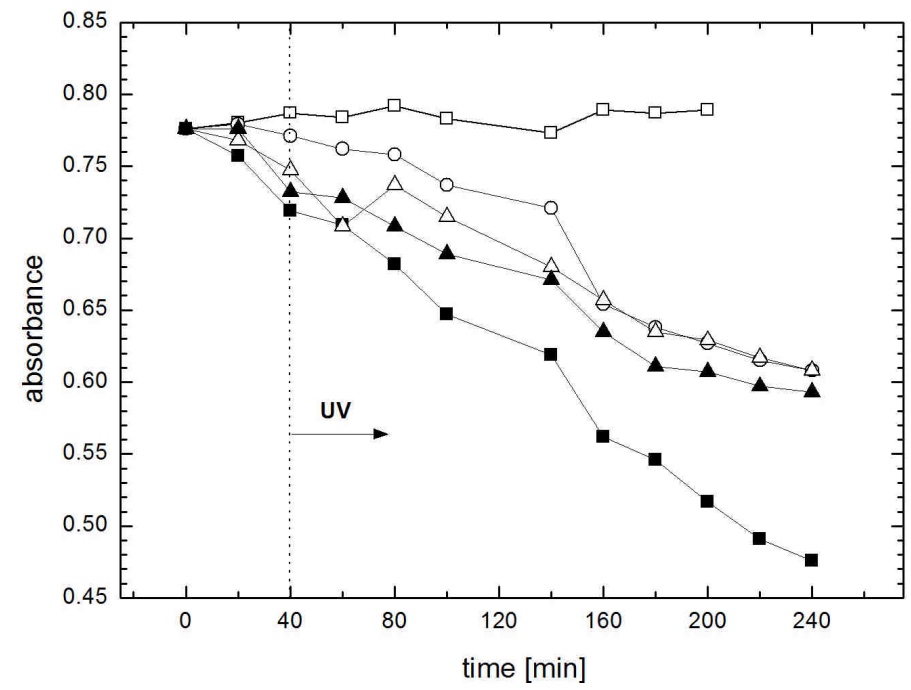

Fig. 6. The course of photocatalytic degradation of methylene blue: $\square$ blank, o acrylic paint, $\Delta$ silicone coating, $\boldsymbol{\Delta}$ lime plaster, $\boldsymbol{\square}$ silicate paint 
We can see on the graph that the rate of the methylene blue decomposition depend significantly also on the support used for preparation of coatings. The highest photocatalytic activity shows material with composite treated silicate paint.

The composite was after the laboratory testing applicated as a painting on the concrete outside wall. In Figure 7 is shown the photo of the concrete wall which was partly treated with the composite.

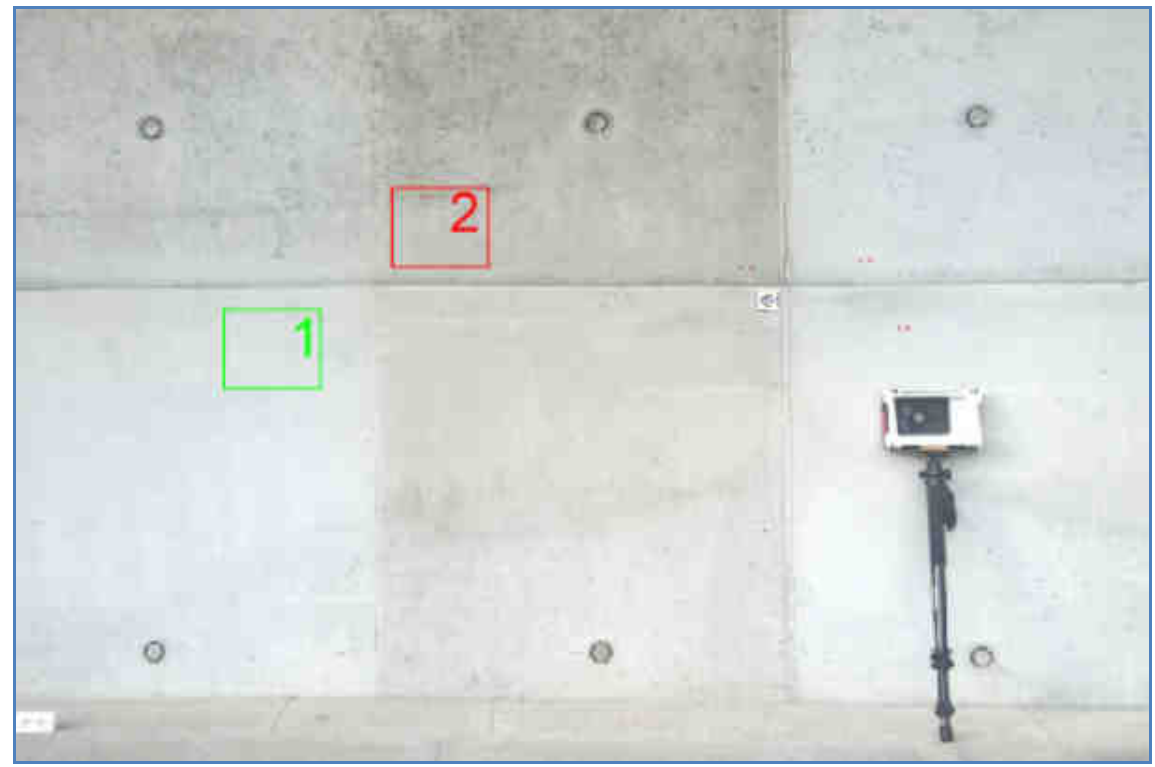

Fig. 7. The photo of concrete outside wall: green line - composite coated part; 1 - composite treated part for analysis, 2 - not treated part for analysis

The painted parts are delimited by green line. Picture analysis was made from the parts identified as 1 and 2. The intensity change analysis of the surface colour demonstrated significant difference between treated parts of the wall and not treated one. This difference is also clearly eye-recognizable, the parts coated with composite are lighter and shows less dirty appearance than the parts without photocatalyst.

\section{Photocatalytic antibacterial characterization}

We determined the antibacterial photocatalytic effect on the formation of colony by bacterium Escherichia coli and bacteria Staphylococcus. The results from CFU assay show that in case of the composite coated samples we observed significant reduction in the number of colony under the illumination. There were determined very small differences between the antibacterial activity towards gram negative $E$. coli and gram positive Staphylococcus bacteria. The number of $E$. coli was reduced from $10^{8}$ to $10^{5}$ and the number of Staphylococcus was reduced from $10^{7}$ to $10^{5}$. Accordingly about $99 \%$ of colony by both bacteria was not formed on the coated glass during the illumination.

The slightly higher immunity of Staphylococcus towards photocatalytic degradation can be explained by its more complex cell membrane. 


\section{Conclusions}

$\mathrm{SiO}_{2}-\mathrm{TiO}_{2}$ based nanocomposite material was developed and its use for protection of building surfaces against the biological and air pollutants was evaluated. The material demonstrated strong antibacterial effect and inhibits most of the tested organisms. Also the self-cleaning properties indicate reasonable results, which were also confirmed, beside the laboratory tests, by testing in real conditions. Consequently it can be expected that the application of the photocatalytic $\mathrm{TiO}_{2}-\mathrm{SiO}_{2}$ composite brings the improvement of life service and appearance of various urban objects and monuments.

\section{Acknowledgements}

The results of this project LD14059 were obtained through the financial support of the Ministry of Education, Youth and Sports of the Czech Republic in the framework of the targeted support of the "The nano-surfaces for cultural heritage" and was also supported by the Ministry of Education, Youth and Sports within the SGS project no. 21066/115 on the Technical University of Liberec.

\section{References}

[1] Fujishima A, Honda K. Electrochemical photolysis of water at a semiconductor electrode. Nature. 1972;238:37-38. DOI: 10.1038/238037a0.

[2] Caballero L, Whitehead K A, Allen NS, Verran J. Inactivation of Escherichia coli on immobilized $\mathrm{TiO}_{2}$ using fluorescent light. J Photochem Photobiol Chem. 2009;202:92-98. DOI: 10.1016/j.jphotochem.2008.11.005.

[3] Göransson G, Jirkovský JS, Krtil P, Ahlberg E. Oxidation of propenol on nanostructured Ni and NiZn electrodes in alkaline solution. Electrochimica Acta. 2014;139:345-355. DOI: 10.1016/j.electacta.2014.06.169.

[4] Venkata Subba Rao K, Rachel A, Subrahmanyam M, Boule P. Immobilization of $\mathrm{TiO}_{2}$ on pumice stone for the photocatalytic degradation of dyes and dye industry pollutants. Appl Catal B Environ. 2003;46:77-85. DOI: 10.1016/S0926-3373(03)00199-1.

[5] Rasalingam S, Peng R, Koodali RT. Removal of hazardous pollutants from wastewaters: applications of $\mathrm{TiO}_{2}-\mathrm{SiO}_{2}$ mixed oxide materials. J Nanomater. 2014;e617405. DOI: 10.1155/2014/617405.

[6] Zhang L, Mohamed HH, Dillert R, Bahnemann D. Kinetics and mechanisms of charge transfer processes in photocatalytic systems: A review. J Photochem Photobiol C Photochem Rev. 2012;13:263-276. DOI: 10.1016/j.jphotochemrev.2012.07.002.

[7] Radecka M, Rekas M, Trenczek-Zajac A, Zakrzewska K. Importance of the band gap energy and flat band potential for application of modified $\mathrm{TiO}_{2}$ photoanodes in water photolysis. J Power Sources. 2008;181:46-55. DOI: 10.1016/j.jpowsour.2007.10.082.

[8] Malato S, Fernández-Ibáñez P, Maldonado MI, Blanco J, Gernjak W. Decontamination and disinfection of water by solar photocatalysis: Recent overview and trends. Catal Today. 2009;147:1-59. DOI: 10.1016/j.cattod.2009.06.018.

[9] Mohamed HH, Bahnemann DW. The role of electron transfer in photocatalysis: Fact and fictions. Appl Catal B Environ. 2012;128:91-104. DOI: 10.1016/j.apcatb.2012.05.045.

[10] Fujishima A, Zhang X, Tryk DA. $\mathrm{TiO}_{2}$ photocatalysis and related surface phenomena. Surf Sci Rep. 2008;63:515-582. DOI: 10.1016/j.surfrep.2008.10.001.

[11] Zielińska-Jurek A, Zaleska A. Ag/Pt-modified $\mathrm{TiO}_{2}$ nanoparticles for toluene photooxidation in the gas phase. Catal Today. 2014;230:104-111. DOI: 10.1016/j.cattod.2013.11.044.

[12] Chang S, Liu W. The roles of surface-doped metal ions (V, Mn, Fe, Cu, Ce, and W) in the interfacial behavior of $\mathrm{TiO}_{2}$ photocatalysts. Appl Catal B Environ. 2014;156-157:466-475. DOI: 10.1016/j.apcatb.2014.03.044.

[13] Sun H, Wang S, Ang HM, Tadé MO, Li Q. Halogen element modified titanium dioxide for visible light photocatalysis. Chem Eng J. 2010;162:437-447. DOI: 10.1016/j.cej.2010.05.069. 
[14] Pelaez M, Nolan NT, Pillai SC, Seery MK, Falaras P, Kontos AG, et al. A review on the visible light active titanium dioxide photocatalysts for environmental applications. Appl Catal B Environ. 2012;125:331-349. DOI: 10.1016/j.apcatb.2012.05.036.

[15] Nakata K, Fujishima A. $\mathrm{TiO}_{2}$ photocatalysis: Design and applications. J Photochem Photobiol C Photochem Rev. 2012;13:169-189. DOI: 10.1016/j.jphotochemrev.2012.06.001.

[16] Chen X, Mao SS. Titanium dioxide nanomaterials: Synthesis, properties, modifications, and applications. Chem Rev. 2007; 2891-2959. DOI: 10.1021/cr0500535.

[17] Monteiro RAR, Lopez, FVZ, Silva AMT, Angelo J, Silva GV, Mendes AM, et al. Are $\mathrm{TiO}_{2}$-based exterior paints useful catalysts for gas-phase photooxidation processes? A case study on n-decane abatement for air detoxification. Appl Catal B Environ. 2014;147:988-999. DOI: 10.1016/j.apcatb.2013.09.031.

[18] Kolen'ko YV, Churagulov BR, Kunst M, Mazerolles L, Colbeau-Justin C. Photocatalytic properties of titania powders prepared by hydrothermal method. Appl Catal B Environ. 2004;54:51-58. DOI: 10.1016/j.apcatb.2004.06.006.

[19] La Russa MF, Ruffolo SA, Rovella N, Belfiore CM, Palermo AN, Guzzi MT, et al. Multifunctional $\mathrm{TiO}_{2}$ coatings for cultural heritage. Prog Org Coat. 2012;74:186-191. DOI: 10.1016/j.porgcoat.2011.12.008.

[20] La Russa MF, Macchia A, Ruffolo SA, De Leo F, Barberio M, Barone P, et al. Testing the antibacterial activity of doped $\mathrm{TiO}_{2}$ for preventing biodeterioration of cultural heritage building materials. Int Biodeterior Biodegrad. 2014;96:87-96. DOI: 10.1016/j.ibiod.2014.10.002.

[21] Houas A, Lachheb H, Ksibi M, Elaloui E, Guillard Ch, Herrmann JM, et al. Photocatalytic degradation pathway of methylene blue in water. Appl Catal B Environ. 2001;31:145-157. DOI: 10.1016/S0926-3373(00)00276-9.

\title{
POWŁOKI FOTOKATALITYCZNE - OBIECUJACY SPOSÓB POPRAWY JAKOŚCI POWIERZCHNI BUDYNKÓW MIEJSKICH
}

\begin{abstract}
Abstrakt: Wraz ze wzrostem zanieczyszczenia powietrza, szczególnie w miastach, następuje coraz szybsze pogorszenie stanu budynków. Jednym z obiecujących, nieinwazyjnych i tanich sposobów zapobiegania niszczeniu budynków wywołanemu zanieczyszczeniem biologicznym lub smogiem jest stosowanie innowacyjnych powłok fotokatalitycznych. W pracy scharakteryzowano przygotowane nanokompozytowe $\mathrm{TiO}_{2}-\mathrm{SiO}_{2}$ systemy fotokatalityczne, wykorzystane do poprawy jakości powierzchni obiektów budowlanych. Strukturę i charakterystykę tekstury przygotowanego nanokompozytu określono metodą mikroskopii elektronowej (SEM, TEM + EDS). Oceniono aktywność fotokatalityczną kompozytu, biorąc pod uwagę jego zdolność do samooczyszczania i aktywność przeciwbakteryjną. Miarą samooczyszczania była degradacja błękitu metylowego. Właściwości samoczyszczące były badane na różnego rodzaju podłożach, powszechnie stosowanych do pokrywania fasad budynków. Do oceny właściwości antybakteryjnych i działania biobójczego wykorzystano Gram-ujemnych bakterie Escherichia coli i Gram-dodatnie bakterie Staphylococcus aureus. Badania wykonano zgodnie ze standardowymi testami ISO. Po badaniach laboratoryjnych kompozyt testowano w warunkach rzeczywistych. Badanym materiałem pokryto zewnętrzne fragmenty betonowego budynku, a po upływie ponad roku oceniono zmiany koloru tych powierzchni.
\end{abstract}

Słowa kluczowe: nanokompozyt $\mathrm{TiO}_{2}-\mathrm{SiO}_{2}$, fotoaktywność, powłoki przezroczyste, samoczyszczące się powierzchnie, antybakteryjna aktywność fotokatalityczna, dziedzictwo architektoniczne 